\title{
Neuroinflammation and $\beta$ Amyloid Deposition in Alzheimer's Disease: In vivo Quantification with Molecular Imaging
}
C. Hommet ${ }^{a-c}$
K. Mondon ${ }^{a-c}$
V. Camus $^{\mathrm{a}-\mathrm{c}}$
M.J. Ribeiro ${ }^{b-d}$
E. Beaufils ${ }^{a}, b$
N. Arlicot ${ }^{b, c}$
P. Corciab, $c$
M. Paccalin ${ }^{\mathrm{C}}$
F. Minier ${ }^{b, c}$
T. Gosselin b, c
G. Page ${ }^{e}$
D. Guilloteau ${ }^{b, c}$
S. Chalon ${ }^{b, c}$

a Memory Clinic (CMRR), Tours University Hospital, b F. Rabelais University, ${ }^{\mathrm{C}}$ Inserm U930, and ${ }^{d}$ Nuclear Medicine Unit, CHRU de Tours, Tours, and e EA 3808, University of Poitiers, Poitiers, France

\section{Key Words}

Neuroinflammation · Translocator protein · Microglia · Alzheimer's disease · Amyloid plaques · Molecular imaging $\cdot\left[{ }^{18} \mathrm{~F}\right] \mathrm{DPA}-714$

\begin{abstract}
Background/Aims: Neuroinflammation plays a crucial role in the pathogenesis of Alzheimer's disease $(A D)$. Its relationship with underlying $\beta$ amyloid deposition remains unclear. In vivo visualization of microglial activation has become possible with the development of molecular imaging ligands when used with positron emission tomography (PET). The translocator protein (TSPO) is upregulated during neuroinflammation. Consequently, targeting TSPO with radiolabeled ligands for PET is an attractive biomarker for neuroinflammation. Methods: $A$ review of the research literature on PET imaging which studied in vivo neuroinflammation in AD subjects and its relationship with amyloid load was performed, including papers published between 2001 and 2012. Results: Six studies were included using either $\left[{ }^{11} \mathrm{C}\right] \mathrm{PK}-11195$ or another non-TSPO radioligand that binds to the monoaminooxidase B. All the studies evaluated amyloid load with $\left[{ }^{11} \mathrm{C}\right] \mathrm{PIB}$. Microglial activation and astrocytosis are potentially early phenomena in AD. However, the individual levels of amyloid deposition and microglial activation were not correlated. Conclusion: Noninvasive in vivo molecular imaging to visualize neuroinflammation in AD may contribute to our understanding of the kinetics of neuroinflammation and its relationship to the hallmarks of the disease. Both are important for the development of future therapeutic modalities and for quantifying the efficacy of future disease-modifying treatments.


Dementia

Cognitive Disorders

\begin{tabular}{l|l}
\hline Dement Geriatr Cogn Disord 2014;37:1-18 \\
\hline DOI: $\underline{10.1159 / 000354363}$ & $\begin{array}{l}\text { (c) 2013 S. Karger AG, Basel } \\
\text { www.karger.com/dem }\end{array}$ \\
\hline
\end{tabular}

Hommet et al.: Neuroinflammation and $\beta$ Amyloid Deposition in Alzheimer's Disease: In vivo Quantification with Molecular Imaging

Alzheimer's disease (AD) is the most common cause of dementia in elderly subjects. AD is characterized by brain lesions like extracellular deposits of $\beta$-amyloid proteins in senile plaques and intracellular neurofibrillary tangles of hyperphosphorylated tau protein, both of which are associated with the loss of neurons [1]. In AD, pathological changes precede the clinical diagnosis of dementia due to $\mathrm{AD}$ [2]. Consequently, a new lexicon was proposed [3, 4] defining the research criteria for the diagnosis of $\mathrm{AD}$ based upon the presence of a specific pattern of episodic memory disturbance (within test conditions of encoding specificity), associated with biomarker positivity, that can include cerebrospinal fluid (CSF) tau, p-tau and $\beta$-amyloid, positron emission tomography (PET) amyloid positivity, medial temporal lobe atrophy on magnetic resonance imaging (MRI) and/or hypometabolism on fluorodeoxyglucose PET. In 2011, the National Institute on Aging-Alzheimer's Association workgroup published recommendations and distinguished the preclinical stages of $\mathrm{AD}$ (presymptomatic phase without any clinical signs) [5], the diagnosis of mild cognitive impairment (MCI) due to $\mathrm{AD}$, also considered as a prodromal phase (MCI-AD) [6], and the final phase, dementia due to $\mathrm{AD}$ (AD dementia) [7]. The development of disease biomarkers for AD [8] in order to identify the pathophysiological processes underlying cognitive impairment has been incorporated into revised diagnosis guidelines [7]. Moreover, postmortem human AD [9, 10] and animal model AD studies [11-13] have reported that inflammatory processes are also implicated in the neuropathology of AD and upregulated levels of pro-inflammatory cytokines [14].

Considering the recent development of molecular imaging, the main aim of this review was to investigate the current evidence on neuroinflammation through in vivo molecular imaging and its relationship with amyloid load in AD subjects in the hope that this may lead to future developments in both diagnosis and therapeutics. Noninvasive in vivo molecular imaging of neuroinflammation may represent a biomarker for early diagnosis, as well as a useful tool for assessing the efficacy of disease-modifying therapeutic strategies.

\section{Neuroinflammation in AD: In vivo Quantification with Molecular Imaging}

\section{Glial and Peripheral Blood Cell Reaction in $A D$}

$\mathrm{AD}$ is characterized histopathologically by neuropathological hallmarks (senile plaques, intracellular neurofibrillary tangles and diffuse loss of neurons). However, prominent activation of the inflammatory processes is also observed in human postmortem studies of AD patients [14-19]. These inflammatory components include microglia activation, which may be considered to be the resident tissue macrophages in the central nervous system (CNS), as well as astrocytosis, both of which surround the plaques. In response to an activating stimulus, activated microglia secrete a variety of inflammatory mediators including cytokines [tumor necrosis factor (TNF) and interleukin (IL)-1 $\beta$, IL- $\alpha$ and IL-6] and chemokines that promote the inflammatory state. Various human and animal studies have demonstrated that neuroinflammation plays a role in amyloidogenesis processing [19-23], although the role of microglia activation during the course of the disease remains poorly understood. Microglial activation may be beneficial in AD by promoting amyloid clearance which may facilitate $\beta$ amyloid elimination [24-28]. However, microglial activation may also produce brain damage via the release of inflammatory mediators, including IL-1 $\beta$, IL-6 and TNF $\alpha$ [27]. Microglial cells may amplify several steps of the amyloid cascade $[24,29]$. Some studies have shown that this inflammatory response was also present at the periphery with increased levels of circulating cytokines and chemokines in plasma [30-32] and in peripheral blood mononuclear cells (PBMCs) [32-34] of patients with AD compared to age-matched controls. Furthermore, in patients with $\mathrm{AD}$, both activated T cells and monocytes are present peripherally [35] and infiltrate around amyloid deposits in the brain [36, 37]. Access into the CNS across the blood- 
brain barrier in $\mathrm{AD}$ patients depends on the inflammatory environment, but the role played by chemokines remains to be elucidated. Some chemokines (e.g. CCL2, CCL5 and CX3CL1) have been quantified in the plasma or CSF of AD patients, and their role in the pathophysiology of AD has been revealed [31,38-41]. An additional argument for the role of systemic inflammation in the pathophysiology of $A D$ is provided by epidemiological studies which suggest that nonsteroidal anti-inflammatory drugs (NSAIDs) may decrease the risk of AD [42-45]. However, randomized controlled trials involving the systemic administration of NSAIDs have reported mixed or inconclusive results, suggesting that we need to identify different treatment effects according to the stage of the disease $[46,47]$.

\section{Translocator Protein Brain Imaging of Neuroinflammation}

Sustained inflammatory responses involve microglia and astrocytes. Microglial cells become activated at every stage in response to a pathological event [48]. The inflammatory reaction involves a dramatic increase in the expression of a mitochondrial transmembrane protein, the translocator protein (TSPO; $18 \mathrm{kDa}$ ), formerly known as the peripheral benzodiazepine receptor (PBR), a receptor located in the outer membrane of mitochondria [49, 50], whose upregulation is considered to be a hallmark of microglial activation. TSPO is an attractive target for imaging cerebral inflammation because it is only modestly expressed in normal brain parenchyma, but is dramatically upregulated during neuroinflammation [27, $51,52]$.

The development of novel PET radioligands with a high affinity for TSPO offers us the possibility of exploring neuroinflammation in vivo. PET imaging of neuroinflammation is a noninvasive imaging technique which uses radioisotope-labeled ligands (such as carbon-11 or fluorine-18) that have a high affinity for binding specifically to the TSPO [10, 53]. The lipophilic nature of the radioligand facilitates its entry across the blood-brain barrier into the CNS and its binding to brain TSPO. Several different PET radioligands are available or are being developed [23]. PK-11195 [1-(2-chlorophenyl)-N-(1-methylpropyl)-3-isoquinoline carboxamide], the reference TSPO radioligand, labeled with carbon-11, was used in animal models for focal ischemia $[51,54,55]$, in human brain ischemia $[56,57]$ and in neurodegenerative diseases $[51,58,59]$.

Imaging studies of neuroinflammation in AD subjects mainly using $\left[{ }^{11} \mathrm{C}\right] \mathrm{PK}-11195$ reported an increase in $\left[{ }^{11} \mathrm{C}\right] \mathrm{PK}-11195$ binding in various cortical regions (entorhinal, frontal, temporoparietal and cingulate cortices) compared to controls [58, 60-63]. Several other putative TSPO-specific ligands with improved pharmacological properties have been developed in preclinical and human studies, including [ $\left.{ }^{18} \mathrm{~F}\right]$ PBR06 [64], [ $\left.{ }^{18} \mathrm{~F}\right]$ PBR28 [65], $\left[{ }^{18} \mathrm{~F}\right] \mathrm{DPA}-713$ [15] and $\left[{ }^{11} \mathrm{C}\right]$ vinpocetine [49]. Another TSPO ligand, $\left[{ }^{11} \mathrm{C}\right] \mathrm{DAA} 1106$, was evaluated in postmortem tissues from patients with neurodegenerative diseases, multiple sclerosis or cerebral infarcts and showed favorable pharmacological properties $[49,50]$. This tracer was evaluated in $\mathrm{AD}$ patients compared to controls [66] and, more recently, in MCI subjects compared to AD patients and controls [67]. [ $\left.{ }^{11} \mathrm{C}\right] \mathrm{DAA} 1106$ retention was higher in the dorsal and medial prefrontal cortex, the lateral temporal cortex, the parietal and occipital cortex, the anterior cingulate cortex and the striatum in AD and MCI patients compared to controls. There was no significant difference in $\left[{ }^{11} \mathrm{C}\right] \mathrm{DAA} 1106$ binding between $\mathrm{MCI}$ and AD patients. In contrast, Varrone et al. [68] failed to demonstrate any significant binding of $\left[{ }^{18} \mathrm{~F}\right] \mathrm{DAA} 1106$ in AD subjects. While $\left[{ }^{11} \mathrm{C}\right] \mathrm{PK}-11195$ and other radioligands are now available for studying in vivo neuroinflammation, some limitations have become apparent. Labeling with carbon- 11 for both $\left[{ }^{11} \mathrm{C}\right] \mathrm{PK}-11195$ and $\left[{ }^{11} \mathrm{C}\right] \mathrm{DAA} 1106$ limits its widespread clinical use (short half-life of carbon-11: $20.4 \mathrm{~min}$ ) [48, 69]. The quantification of TSPO by PET currently uses the cerebellum as a reference tissue [56]. However, this quantification may be confounded by interindividual variability in binding affinity of tracers, suggesting a possible polymor- 
Hommet et al.: Neuroinflammation and $\beta$ Amyloid Deposition in Alzheimer's Disease:
In vivo Quantification with Molecular Imaging

phism in the TSPO binding site [70]. This variability in TSPO binding may be related to an underlying genetic mechanism [70-72]. Consequently, another radiotracer for TSPO, DPA-714, labeled with fluorine 18, has been developed. It has a longer half-life than $\left[{ }^{11} \mathrm{C}\right] \mathrm{PK}-11195$ (110 compared to $20 \mathrm{~min}$ ) and is preferentially employed in multicenter clinical studies. $\left[{ }^{18} \mathrm{~F}\right] \mathrm{DPA}-714$ has a good affinity and specificity for TSPO and no affinity at all for CBR (central benzodiazepine receptor) [73]. $\left.{ }^{18} \mathrm{~F}\right] \mathrm{DPA}-714$ uptake is reversible and reaches a peak within $20 \mathrm{~min}$ after bolus injection and slowly decreases thereafter as has recently been shown in the first human study using this radiotracer [74]. Preliminary data in amyotrophic lateral sclerosis are now available [75].

The in vivo quantification of activated microglia with PET imaging may be a useful tool for attaining a better understanding of the physiopathology of $\mathrm{AD}$, especially the chronological relationship between the hallmarks of the disease (especially amyloid load) and microglial activation. In fact, the role of neuroinflammation and its relationship to $A \beta$ remain controversial. Since the hallmarks of AD appear before the clinical symptoms develop, we can suggest that microglial activation plays an early role in the physiopathology of AD. Consequently, we conducted a systematic review of the literature by including PET imaging studies in which the participants had either AD or MCI (prodromal), and where neuroinflammation was studied analyzing TSPO radioligands and their relationship to amyloid load.

\section{Methods}

Search Strategy

In accordance with the preferred reporting items for systematic reviews and meta-analysis (PRISMA) statement [76], we conducted a search on the online PubMed literature database. The search strategy included studies from 2001 to 2012, using combinations of the following terms: Alzheimer's disease; neuroinflammation; microglial activation, astrocytes, PET imaging; TSPO; carbon 11-labeled PK11195; carbon 11-labeled Pittsburgh compound B; amyloid load. We limited our search results to adult subjects and original research studies in the English language.

\section{Study Selection}

We excluded paper reviews, single reports and molecular imaging which involved other neurological diseases than $\mathrm{AD}$ or nonhuman imaging studies (fig. 1). Consequently, this article consists of a review of published research studies on molecular imaging of neuroinflammation and its relationship with PET amyloid imaging in AD and MCI subjects. We focused on the characteristics of the sample (AD and MCI criteria), the study design, identifying which radiotracers had been used, the primary findings of the studies regarding the relationship between neuroinflammation and amyloid load and correlations with measures of cognition. A summary of the key studies can be found in table 1 .

\section{Results}

PET Imaging of Neuroinflammation and Its Relationship to Amyloid Load in AD

PET imaging studies which assessed the regional relationship between microglial activation and $A \beta$ deposition in $A D$ were all cross-sectional studies and used $\left[{ }^{11} \mathrm{C}\right] \mathrm{PK}-11195$ for quantifying neuroinflammation and ${ }^{11} \mathrm{C}$-Pittsburgh compound $\mathrm{B}\left(\left[{ }^{11} \mathrm{C}\right] \mathrm{PIB}\right)[77,78]$ for measuring the amyloid load (table 1). The first radiotracer to reflect the burden of amyloid plaques in AD patients in vivo was $\left[{ }^{11} \mathrm{C}\right] \mathrm{PIB}[77,78]$, but its use is limited because of the short half-life (20 min) of carbon-11. Newer radiotracers have been developed, using fluorine-18, which are more accessible to clinical research thanks to their longer half-life (110 $\mathrm{min}$ ) [78], e.g. florbetapir [79-85], florbetaben [86, 87], flutemetamol [88] and FDDNP [89]. All have already shown that they are capable of distinguishing AD patients from healthy controls. 
Hommet et al.: Neuroinflammation and $\beta$ Amyloid Deposition in Alzheimer's Disease:

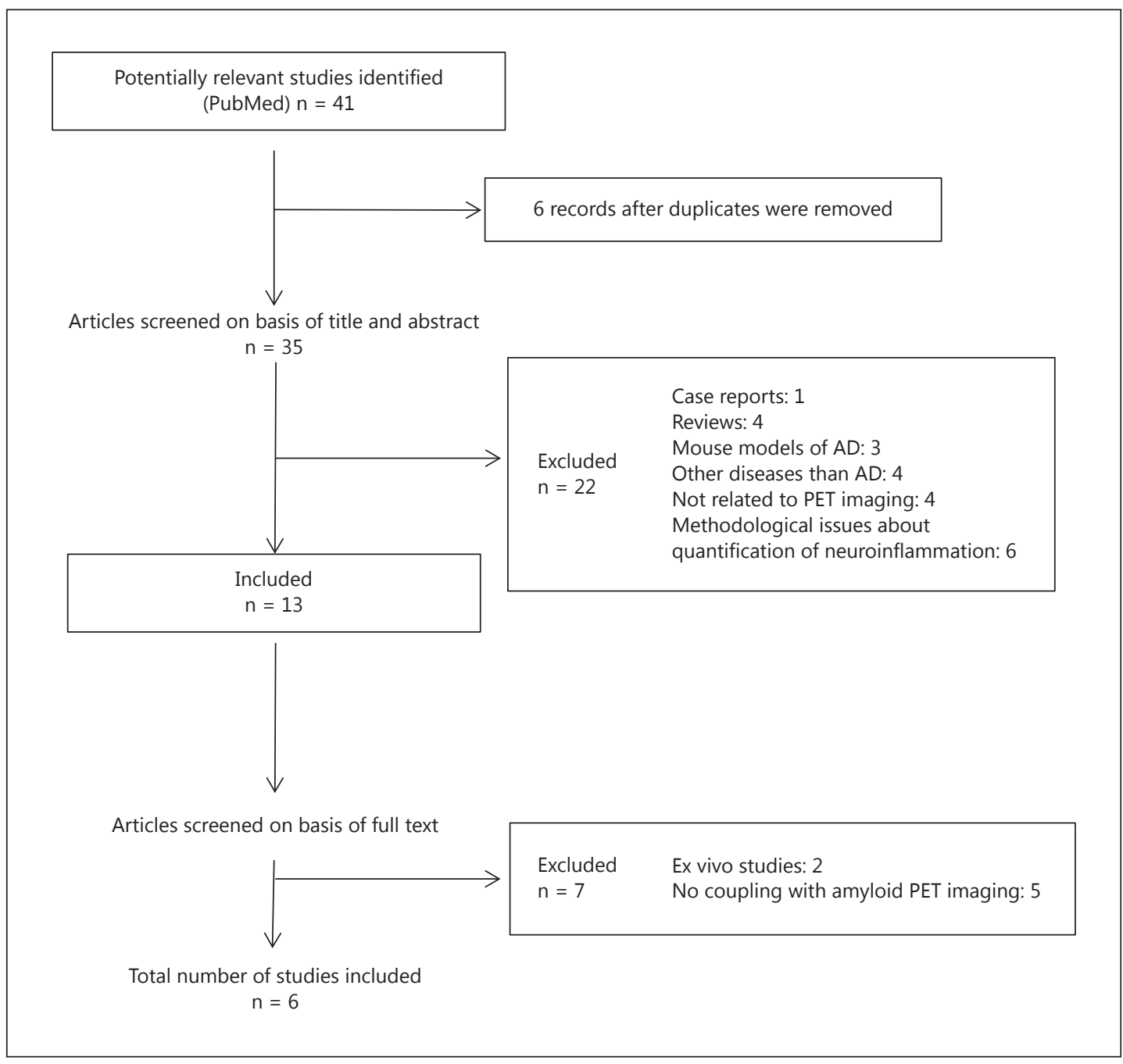

Fig. 1. Flow diagram.

Yokokura et al. [90] reported a significant increase in $\left[{ }^{11} \mathrm{C}\right] \mathrm{PK}-11195 \mathrm{BP}$ in the anterior and posterior cingulate areas in AD subjects compared to controls, who demonstrated a more robust increase in $\left[{ }^{11} \mathrm{C}\right] \mathrm{PIB}$ accumulation. $\left[{ }^{18} \mathrm{~F}\right] \mathrm{FDG}$ uptake was also reduced in these regions as has been classically reported in $\mathrm{AD}$ in the early stage of the disease. However, there was also an increase in PIB binding in broader regions, such as the parietal, temporal and frontal areas, indicating a lack of coupling between amyloid deposits and microglial activation. Wiley et al. [91] confirmed that there was no difference in brain $\left[{ }^{11} \mathrm{C}\right] \mathrm{PK}-11195$ retention between $\mathrm{AD}, \mathrm{MCI}$ and control subjects, or in the presence or absence of $\mathrm{A} \beta$ deposits, as detected by $\left[{ }^{11} \mathrm{C}\right] \mathrm{PIB}$ retention. Okello et al. [92] compared the in vivo pattern of amyloid deposition and microglial activation in 14 subjects with amnestic MCI to 2 other groups: 22 AD subjects who had $\left[{ }^{11} \mathrm{C}\right] \mathrm{PIB}$ PET and 15 who had $\left[{ }^{11} \mathrm{C}\right] \mathrm{PK}-11195$ PET. Fourteen healthy controls underwent $\left[{ }^{11} \mathrm{C}\right] \mathrm{PIB}$ PET and 10 underwent $\left[{ }^{11} \mathrm{C}\right] \mathrm{PK}-11195 \mathrm{PET}$. The results confirmed the existence of an increase in $\left[{ }^{11} \mathrm{C}\right] \mathrm{PIB}$ uptake in $50 \%$ of the MCI subjects (PIB positive). However, only $38 \%$ of the subjects had an increase in $\left[{ }^{11} \mathrm{C}\right] \mathrm{PK}-11195$ uptake which was not correlated with $\left[{ }^{11} \mathrm{C}\right] \mathrm{PIB}$, confirming the absence of correlation between the regional level of $\left[{ }^{11} \mathrm{C}\right] \mathrm{PK}-11195$ 
Table 1. Molecular brain imaging studies of neuroinflammation and relationship with amyloid load in human AD and MCI subjects

\begin{tabular}{|c|c|c|c|c|c|c|}
\hline Study & Populations & $\begin{array}{l}\text { PET imaging } \\
\text { of neuroin- } \\
\text { flammation }\end{array}$ & $\begin{array}{l}\text { PET imaging } \\
\text { of amyloid } \\
\text { load }\end{array}$ & $\begin{array}{l}\text { Outcome measures and } \\
\text { statistical analysis }\end{array}$ & Main results & $\begin{array}{l}\text { Correlations with } \\
\text { cognition }\end{array}$ \\
\hline $\begin{array}{l}\text { Edison } \\
\text { et al. [60] }\end{array}$ & $\begin{array}{l}A D: \mathrm{n}=13 \text {; DSM IV and } \\
\text { McKhann et al.'s [132] criteria; } \\
\text { mean age } 65.6 \pm 4.6 \text { years; } \\
\text { duration of diagnosis } 14.5 \pm 6.5 \\
\text { months; subjects with } \\
\text { significant white matter disease } \\
\text { were excluded } \\
\text { Controls: } \mathrm{n}=24\end{array}$ & $\begin{array}{l}{\left[{ }^{11} \mathrm{C}\right] \mathrm{PK}-} \\
11195 \text { for } \\
10 \text { controls } \\
\text { and } 13 \mathrm{AD} \\
\text { subjects }\end{array}$ & $\begin{array}{l}{\left[{ }^{11} \mathrm{C}\right] \mathrm{PIB}} \\
\text { for } 14 \\
\text { controls } \\
\text { and } 13 \mathrm{AD} \\
\text { subjects }\end{array}$ & $\begin{array}{l}{\left[{ }^{11} \mathrm{C}\right] \mathrm{PK}-11195 \mathrm{BP} ;} \\
{\left[{ }^{11} \mathrm{C}\right] \mathrm{PIB} \text { uptake ratio images: }} \\
\text { target region to cerebellar } \\
{\left[{ }^{11} \mathrm{C}\right] \mathrm{PIB} \text { uptake ratio image; }} \\
\text { one-tailed Student's t test } \\
\text { (ROI data); } \\
\text { Spearman's rho correlation }\end{array}$ & $\begin{array}{l}A D \text { : increase in PK-11195 } \\
\text { binding related with } \beta \\
\text { amyloid load in frontal, } \\
\text { temporal, parietal, } \\
\text { occipital and cingulated } \\
\text { cortex (p < 0.05); } \\
\text { PK-11195 signal was not } \\
\text { correlated with amyloid } \\
\text { load }\end{array}$ & $\begin{array}{l}A D \text { : significant } \\
\text { inverse correlation } \\
\text { between MMSE } \\
\text { scores and PK-11195 } \\
\text { binding in posterior } \\
\text { cingulate, parietal } \\
\text { and frontal regions } \\
(\mathrm{r}=0.66)\end{array}$ \\
\hline $\begin{array}{l}\text { Okello } \\
\text { et al. [92] }\end{array}$ & $\begin{array}{l}A D: \mathrm{n}=22 ; \text { McKhann et al.'s } \\
{[132] \text { criteria; mean age } 64.9 \pm} \\
6.4 \text { years; mean duration of } \\
\text { symptoms } 5.5 \pm 3.8 \text { years; } \\
\text { MMSE } 21.5 \pm 3.6 \\
\text { MCI: } \mathrm{n}=14 ; \text { mean age } 66.6 \pm 9.6 \\
\text { years; Petersen et al.'s }[133] \\
\text { criteria for amnestic MCI; } \\
\text { MMSE } 27.7 \pm 1.5 ; \text { subjects with } \\
\text { significant white matter disease } \\
\text { were excluded } \\
\text { Controls: } \mathrm{n}=14\end{array}$ & $\begin{array}{l}{\left[{ }^{11} \mathrm{C}\right] \mathrm{PK}-} \\
11195: \\
\text { AD: } 15 / 22 \\
\text { MCI: } 14 / 14 \\
\text { Controls: } \\
\text { 10/14 }\end{array}$ & $\begin{array}{l}{\left[{ }^{11} \mathrm{C}\right] \text { PIB: }} \\
\text { AD: } 22 / 22 \\
\text { MCI: } 14 / 14 \\
\text { Controls: } 14\end{array}$ & $\begin{array}{l}\text { PIB relative volume of } \\
\text { distribution; PK-11195 BP; } \\
\text { ANOVA repeated measures; } \\
\text { univariate analysis of } \\
\text { variance between groups; } \\
\text { Pearson's rank correlation } \\
\text { coefficient: to study } \\
\text { correlation between PIB and } \\
\text { PK-11195 BP in MCI } \\
\text { subjects; Spearman's rank } \\
\text { correlation coefficient: } \\
\text { between PET measures, } \\
\text { MMSE and duration of } \\
\text { symptoms }\end{array}$ & $\begin{array}{l}M C I \text { : increased PIB uptake } \\
\text { in } 7 / 14 \mathrm{MCI} \text { increase in } \\
\text { PK-11195 uptake in } 5 / 13 \\
\text { MCI; no correlation with } \\
\text { PIB; MCI with increased } \\
{\left[{ }^{11} \mathrm{C}\right] \mathrm{PIB} \text { retention had }} \\
\text { increased cortical }\left[{ }^{11} \mathrm{C}\right] \mathrm{PK}- \\
11195 \mathrm{BP}(\mathrm{p}<0.036) ; \text { no } \\
\text { correlation between } \\
\text { individual regional } \\
\text { PK-11195 binding and PIB } \\
\text { retention }\end{array}$ & $\begin{array}{l}A D \text { and } M C I \text { : no } \\
\text { correlation between } \\
\text { MMSE, duration of } \\
\text { the disease and } \\
{\left[{ }^{11} \mathrm{C}\right] \text { PIB retention or }} \\
{\left[{ }^{11} \mathrm{C}\right] \mathrm{PK}-11195} \\
\text { binding; in the } \\
\text { PIB-negative MCI } \\
\text { subjects, lower } \\
\text { MMSE score } \\
\text { correlated with } \\
\text { higher PK-11195 } \\
\text { binding in anterior } \\
\text { cingulate and } \\
\text { temporal cortex } \\
\text { (p < } 0.05 \text { ) }\end{array}$ \\
\hline $\begin{array}{l}\text { Wiley } \\
\text { et al. [91] }\end{array}$ & $\begin{array}{l}A D: \mathrm{n}=6 ; \text { McKhann et al.'s } \\
\text { [132] criteria and DSM IV } \\
\text { criteria; mean age } 64.9 \pm 6.4 \\
\text { years; MMSE } 13-28 ; \\
\text { no restriction for } \\
\text { anticholinesterase drug; no } \\
\text { details about the duration of } \\
\text { the disease } \\
\text { MCI: } \mathrm{n}=6 \text {; no details about } \\
\text { diagnosis criteria; mean age } \\
71.8 \pm 8.5 \text { years; MMSE } 27-30 \\
\text { Controls: } \mathrm{n}=5 \text {; mean age } 72 \pm \\
5.9 \text { years }\end{array}$ & $\begin{array}{l}{\left[{ }^{11} \mathrm{C}\right] \mathrm{PK}-} \\
11195\end{array}$ & {$\left[{ }^{11} \mathrm{C}\right] \mathrm{PIB}$} & $\begin{array}{l}\text { Analysis of variance with } \\
\text { post-test Bonferroni } \\
\text { correction to compare } \\
{\left[{ }^{11} \mathrm{C}\right] \mathrm{PIB} \text { (SUV) and }} \\
{\left[{ }^{11} \mathrm{C}\right] \mathrm{PK}-11195 \text { (BP) fixation }} \\
\text { between groups; } \\
\text { nonparametric Mann- } \\
\text { Whitney test to compare } \\
\text { data between } \\
{\left[{ }^{11} \mathrm{C}\right] \text { PIB-positive and }} \\
\text {-negative groups; Pearson's } \\
\text { correlation coefficient to } \\
\text { study the relationship } \\
\text { between }\left[{ }^{11} \mathrm{C}\right] \mathrm{PK}-11195 \text { and } \\
{\left[{ }^{11} \mathrm{C}\right] \mathrm{PIB} \text { retention }}\end{array}$ & $\begin{array}{l}{\left[{ }^{11} \mathrm{C}\right] \mathrm{PK}-11195 \mathrm{BP} \text { : no }} \\
\text { significant differences in } \\
\mathrm{BP} \text { between subject groups } \\
\text { and no significant } \\
\text { difference between } \\
\text { PIB-negative and } \\
\text { PIB-positive groups; no } \\
\text { significant correlation } \\
\text { between indices of } \\
{\left[{ }^{11} \mathrm{C}\right] \mathrm{PK}-11195 \text { and }} \\
{\left[{ }^{11} \mathrm{C}\right] \mathrm{PIB} \text { retention }}\end{array}$ & Not evaluated \\
\hline $\begin{array}{l}\text { Yokokura } \\
\text { et al. [90] }\end{array}$ & $\begin{array}{l}A D: \mathrm{n}=11 ; \text { McKhann et al.'s } \\
\text { [132] criteria and DSM IV } \\
\text { criteria; mean age } 70.6 \pm 6.4 \\
\text { years; exclusion: subjects with } \\
\text { significant white matter } \\
\text { disease, donepezil and NSAIDs; } \\
\text { disease duration } 2.4 \pm 1.7 \text { years; } \\
\text { MMSE } 21.9 \pm 3.5 \\
\text { Controls: } \mathrm{n}=10\end{array}$ & $\begin{array}{l}{\left[{ }^{11} \mathrm{C}\right] \mathrm{PK}-} \\
11195, \\
\text { coupling } \\
\text { with } \\
{\left[{ }^{18} \mathrm{~F}\right] \mathrm{FDG}}\end{array}$ & {$\left[{ }^{11} \mathrm{C}\right] \mathrm{PIB}$} & $\begin{array}{l}{\left[{ }^{11} \mathrm{C}\right] \mathrm{PK}-11195 \mathrm{BP} ;} \\
{\left[{ }^{11} \mathrm{C}\right] \mathrm{PIB} \text { BP; }\left[{ }^{18} \mathrm{~F}\right] \mathrm{FDG} \text { SUV; }} \\
\text { t test for comparisons } \\
\text { between groups; Pearson's } \\
\text { correlation between MMSE } \\
\text { scores and PET parameters }\end{array}$ & $\begin{array}{l}A D \text { : significant increase in } \\
{\left[{ }^{11} \mathrm{C}\right] \mathrm{PK}-11195 \mathrm{BP} \text { in the }} \\
\text { anterior and posterior } \\
\text { cingulate area; significant } \\
\text { negative correlation } \\
\text { between }\left[{ }^{11} \mathrm{C}\right] \mathrm{PK}-11195 \\
\text { and }\left[{ }^{11} \mathrm{C}\right] \mathrm{PIB} \text { uptake in the } \\
\text { posterior cingulate cortex } \\
(\mathrm{r}=-0.84) \text {, the area with } \\
\text { the most severe reduction } \\
\text { in the }\left[{ }^{18} \mathrm{~F}\right] \mathrm{FDG}\end{array}$ & $\begin{array}{l}\text { Inverse correlation } \\
\text { between MMSE score } \\
\text { and }\left[{ }^{11} \mathrm{C}\right] \mathrm{PK}-11195 \\
\text { BP values, but not } \\
{\left[{ }^{11} \mathrm{C}\right] \mathrm{PIB} \text { in left }} \\
\text { anterior cingulate } \\
\text { cortex }(\mathrm{r}=0.9) \text {, left } \\
\text { precuneus }(\mathrm{r}=0.8) \\
\text { and left } \\
\text { hippocampus } \\
(\mathrm{r}=0.79)\end{array}$ \\
\hline $\begin{array}{l}\text { Santillo } \\
\text { et al. [93] }\end{array}$ & $\begin{array}{l}A D: \mathrm{n}=9 ; \text { McKhann et al.'s } \\
{[132] \text { criteria and DSM IV }} \\
\text { criteria; MMSE } 10-16 ; \text { median } \\
\text { age } 82 \text { years (range } 71-85 \text { ); } \\
\text { median time since diagnosis } 15 \\
\text { months; all patients except } 2 \\
\text { received symptomatic } \\
\text { treatment; no one was treated } \\
\text { with MAO inhibitors } \\
\text { Controls: } \mathrm{n}=11 ; \text { median age } 67 \\
\text { years (range } 60-71 \text { ) }\end{array}$ & {$\left[{ }^{11} \mathrm{C}\right] \mathrm{DED}$} & $\begin{array}{l}{\left[{ }^{11} \mathrm{C}\right] \mathrm{PIB}} \\
\text { (except for } \\
\text { controls) }\end{array}$ & $\begin{array}{l}{\left[{ }^{11} \mathrm{C}\right] \text { DED binding; }} \\
{\left[{ }^{11} \mathrm{C}\right] \text { PIB SUV; Mann-Whitney }} \\
\text { two-sided test (with } \\
\text { Bonferroni correction) }\end{array}$ & $\begin{array}{l}A D \text { : significantly higher } \\
{\left[{ }^{11} \mathrm{C}\right] D E D \text { retention in }} \\
\text { frontal ( } 35 \% \text { increase), } \\
\text { parietal ( } 35.2 \% \text { increase) } \\
\text { and medial temporal lobes } \\
\text { (22.3\% increase) (1 } \\
\text { subject was PIB negative, } \\
1 \text { subject fulfilled the } \\
\text { diagnosis of Lewy body } \\
\text { disease } 3 \text { months later); } \\
\text { significant correlation ( } \mathrm{r}= \\
0.492) \text { between }\left[{ }^{11} \mathrm{C}\right] \mathrm{DED} \\
\text { and PIB retention values }\end{array}$ & Not evaluated \\
\hline
\end{tabular}


Table 1 (continued)

\begin{tabular}{|c|c|c|c|c|c|c|}
\hline Study & Populations & $\begin{array}{l}\text { PET imaging } \\
\text { of neuroin- } \\
\text { flammation }\end{array}$ & $\begin{array}{l}\text { PET imaging } \\
\text { of amyloid } \\
\text { load }\end{array}$ & $\begin{array}{l}\text { Outcome measures and } \\
\text { statistical analysis }\end{array}$ & Main results & $\begin{array}{l}\text { Correlations with } \\
\text { cognition }\end{array}$ \\
\hline $\begin{array}{l}\text { Carter } \\
\text { et al. [69] }\end{array}$ & $\begin{array}{l}A D: \mathrm{n}=7 ; \text { McKhann et al.'s } \\
{[132] \text { criteria; MMSE } 24.7 \pm 5.7 ;} \\
\text { mean age } 65 \pm 8.3 \text { years } \\
M C I: \mathrm{n}=8 \text {; Petersen et al.'s } \\
\text { [133] criteria; mean age } 62.6 \pm \\
7.5 \text { years; MMSE } 27.5 \pm 2.1 \\
\text { Controls: } \mathrm{n}=14 ; \text { mean age } \\
64.7 \pm 3.6 \text { years }\end{array}$ & $\begin{array}{l}{\left[{ }^{11} \mathrm{C}\right] \mathrm{DED},} \\
\text { coupling } \\
\text { with } \\
{\left[{ }^{18} \mathrm{~F}\right] \mathrm{FDG}}\end{array}$ & $\begin{array}{l}{\left[{ }^{11} \mathrm{C}\right] \mathrm{PIB}} \\
\text { (except for } \\
\text { controls) }\end{array}$ & $\begin{array}{l}{\left[{ }^{11} \mathrm{C}\right] \mathrm{DED} \text { binding; }} \\
{\left[{ }^{11} \mathrm{C}\right] \mathrm{PIB} \text { retention; }} \\
{\left[{ }^{18} \mathrm{~F}\right] \text { FDG uptake; }} \\
\text { ANOVA analysis of the } \\
\text { regional }\left[{ }^{11} \mathrm{C}\right] \mathrm{DED} \mathrm{BP} ; \\
\text { one-tailed Pearson's } \\
\text { correlations with Bonferroni- } \\
\text { corrected p value of } 0.05 \text { for } \\
\text { the } 3 \text { PET comparisons; } \\
\text { MCI subjects were divided } \\
\text { into }\left[{ }^{11} \mathrm{C}\right] \mathrm{PIB} \text { positive and } \\
{\left[{ }^{11} \mathrm{C}\right] \mathrm{PIB} \text { negative }} \\
\text { (comparison with AD with a } \\
\text { Kruskal-Wallis test) }\end{array}$ & $\begin{array}{l}\text { Significant group effect in } \\
\text { the bilateral frontal cortex } \\
\text { and parietal cortex; } \\
\text { post hoc analysis: } \\
\left.\text { increased [ }{ }^{11} \mathrm{C}\right] \mathrm{DED} \\
\text { binding in MCI compared } \\
\text { with controls; MCI PIB- } \\
\text { positive subjects } \\
\text { demonstrated the highest } \\
\left.{ }^{[11} \mathrm{C}\right] \mathrm{DED} \text { binding in } \\
\text { bilateral frontal and } \\
\text { parietal cortex of the } 3 \\
\text { groups (MCI PIB positive, } \\
\text { MCI PIB negative and AD); } \\
\text { no regional correlation } \\
\text { between the } 3 \text { PET tracers }\end{array}$ & Not evaluated \\
\hline
\end{tabular}

and $\left[{ }^{11} \mathrm{C}\right] \mathrm{PIB}$ binding. In contrast to these previous reports, Edison et al. [60] found an increase in $\left[{ }^{11} \mathrm{C}\right] \mathrm{PK}-11195$ binding in $13 \mathrm{AD}$ subjects. These subjects had an increase in amyloid load, measured by the $\left[{ }^{11} \mathrm{C}\right] \mathrm{PIB}$ in these areas. A more recent study investigated the relationship between fibrillar $A \beta$ and astrocytes in $A D$ and MCI subjects [69] using the PET tracer $\left[{ }^{11} \mathrm{C}\right]$-deuterium-L-deprenyl $\left(\left[{ }^{11} \mathrm{C}\right] \mathrm{DED}\right)$. This tracer has a high affinity and specificity for monoamine oxidase $\mathrm{B}$ (MAO-B) located in astrocytes. $\left[{ }^{11} \mathrm{C}\right] \mathrm{PIB}$ was used to measure $\mathrm{A} \beta$ deposition. The authors reported increased $\left[{ }^{11} \mathrm{C}\right] \mathrm{DED}$ binding in the bilateral frontal and parietal cortex in MCI subjects compared to normal controls. The increase in $\left[{ }^{11} \mathrm{C}\right] \mathrm{DED}$ binding was more pronounced in the $\left[{ }^{11} \mathrm{C}\right] \mathrm{PIB}$-positive MCI subjects. Santillo et al. [93] confirmed the increased $\left[{ }^{11} \mathrm{C}\right] \mathrm{DED}$ binding in the frontal, parietal and temporal lobes in $\mathrm{AD}$ compared to controls and a significant correlation between binding potential (BP) and PIB retention value. These results suggest that there was an increased number of astrocytes reacting in $\mathrm{AD}$ as early as in the predementia state.

\section{Neuroinflammation and Cognitive Decline in $A D$}

Patients with AD usually have a progressive clinical course, although the rate of progression varies widely among subjects [94]. Approximately $10-30 \%$ of AD cases undergo rapid cognitive decline [94] which is associated with a greater loss of autonomy and a higher mortality rate than in those who have a slower progression of the disease [95-98]. Why some AD subjects decline more rapidly than others is not clearly understood. Several factors have been suggested to contribute to disease progression [94, 99]: demographic factors (level of education, age), clinical features (extrapyramidal signs, age of onset of the disease, nutritional status) [100-103], presence of psychotic symptoms [104], cholinesterase inhibitor treatment $[105,106]$, genetic factors [apolipoprotein E (APOE) $\varepsilon 4$ allele] $[97,107,108]$, cerebrovascular disease and vascular risk factors [109-125]. Even though several demographic, clinical or genetic factors have been proposed for explaining the rate of decline in $\mathrm{AD}$, they do not fully explain the variability observed in the different rates of clinical progression. Recently, it has been shown that peripheral markers of systemic inflammation are associated with an increase in cognitive decline [126]. Microglial activation could be related to disease activity and progression. Therefore, molecular imaging of microglia activation may prove to be an important biomarker of cognitive decline in AD. 
Only a few studies have assessed the relationship between microglial activation measured with $\left[{ }^{11} \mathrm{C}\right] \mathrm{PK}-11195$ uptake and cognition in $\mathrm{AD}$ or MCI subjects $[60,90,92]$ (table 1). In AD patients, $\left[{ }^{11} \mathrm{C}\right] \mathrm{PK}-11195$ signals were inversely correlated with cognitive function as measured with Mini-Mental State Examination (MMSE) scores, but there was no direct relationship between $\left[{ }^{11} \mathrm{C}\right] \mathrm{PK}-11195$ binding and amyloid load measured with $\left[{ }^{11} \mathrm{C}\right] \mathrm{PIB}[60]$. In the AD group, Yokokura et al. [90] found a significant negative correlation between MMSE scores and $\left[{ }^{11} \mathrm{C}\right] \mathrm{PK}-11195 \mathrm{BP}$ in the left anterior cingulate cortex, left precuneus, left hippocampus and left middle frontal cortex, but not between MMSE scores and the uptake of $\left[{ }^{11} \mathrm{C}\right] \mathrm{PIB}$ in the limbic, precuneus and prefrontal areas [90].

Considering the new diagnostic criteria of $\mathrm{AD}$, it seems important to study the profile of neuroinflammation in MCI (prodromal AD). MCI subjects are more likely to have higher levels of systemic inflammation (cross-sectional relationship) [127], although we do not know the impact of systemic inflammation on the progression from MCI to AD. In MCI subjects, only a few molecular imaging studies have reported an increase in binding compared to controls $[67,69,92]$ (table 1). Yasuno et al. [67] evaluated PBR binding in MCI subjects using PET $\left[{ }^{11} \mathrm{C}\right] \mathrm{DAA} 1106$, another PBR ligand. $\left[{ }^{11} \mathrm{C}\right] \mathrm{DAA} 1106$ binding was increased in 6 of $7 \mathrm{MCI}$ subjects compared to controls. There was no significant difference in BP between MCI and AD. Five of the $7 \mathrm{MCI}$ subjects who were followed for 5 years eventually developed AD and 1 was diagnosed with Lewy body disease [67]. Schuitemaker et al. [128] studied [ $\left.{ }^{11} \mathrm{C}\right] \mathrm{PK}-11195$ binding in $10 \mathrm{MCI}$ subjects and compared them with $19 \mathrm{AD}$ patients and 21 healthy controls. They reported increased binding in the occipital lobe in AD compared to controls, but no difference in PK-11195 binding between clinically stable MCI subjects and those who progressed to dementia. There was no correlation between BP and cognitive function. These results suggest that increased TSPO binding in MCI subjects may indicate that microglial activation precedes the onset of dementia. Moreover, the results of molecular imaging studies combining molecular imaging of the amyloid load and microglial activation, especially in prodromal $\mathrm{AD}$, suggest that a regional increase in TSPO binding in prodromal AD reflects early changes associated with $A \beta$ deposition which occurs before structural changes and cognitive impairment become apparent. We should expect increased TSPO binding in prodromal AD which progresses to dementia, and perhaps earlier in preclinical AD. Subjective memory impairment, also called subjective cognitive impairment, is generally considered to be a pre-MCI condition during the clinical course of $\operatorname{AD}[129,130]$, if the patient's complaint of cognitive impairment can be considered a predictor of cognitive decline [131]. Future studies designed to quantify neuroinflammation in patients who have subjective memory complaints are needed to detect preclinical microglial activation, which could be the first indication of the neurodegenerative process.

\section{Discussion}

Microglial activation can be visualized using molecular PET imaging with specific radioligands. The data obtained following the use of molecular imaging for studying neuroinflammation in vivo in $\mathrm{AD}$ subjects support the postulate that microglial activation and astrocytosis are potentially early phenomena. However, individual levels of amyloid deposition and microglial activation are not clearly correlated.

\section{Limitations}

All the studies reported (summarized in table 1) are very promising but had limitations. Firstly, the size of the study group was small in all the studies which selected AD patients using McKhann et al.'s [132] criteria or Petersen et al.'s [133] criteria for MCI without details 
about the MCI subtype. Furthermore, in many of the molecular imaging studies which assessed the relationship between neuroinflammation and amyloid load, the patient's concomitant drug therapy (cholinesterase inhibitors, NSAIDs) was not systematically reported or considered as an exclusion criterion. However, symptomatic drug therapy may influence the binding affinity. In fact, preclinical studies reported that cholinesterase inhibitors may have an influence on neuroinflammation [134] and consequently on TSPO molecular imaging. Moreover, additional genetic or age-related factors may contribute to $A \beta$ formation and microglial activation in AD. Vascular disease may be one of them. Only 3 of the studies excluded subjects with significant cerebrovascular disease in spite of the fact that there is probably a relationship between microglial activation and vascular microangiopathy in AD. In fact, combined neuropathological and postmortem MRI studies have shown that AD subjects with white matter hyperintensities had much greater microglial activation than controls [135, 136]. These findings indicate that there is a potential link between microglial activation and vascular microangiopathy during the course of $\mathrm{AD}$. Consequently, neuroinflammation could be related to vascular dysfunction, especially in elderly AD subjects.

Another limitation may be the sensitivity of the radioligands used for PET imaging which may differ according to each of their characteristics [137]. The majority of the research on neuroinflammation PET radiotracers targets PBR ligands, and $\left[{ }^{11} \mathrm{C}\right] \mathrm{PK}-11195$ was the TSPObinding radioligand most frequently studied. However, new fluorine-labeling radioligands, like $\left[{ }^{18} \mathrm{~F}\right] \mathrm{DPA}-714$, are promising because they can be used in clinical practice. Newer non-TSPO ligands that target other aspects of microglia are emerging. For example, $\left[{ }^{11} \mathrm{C}\right] \mathrm{DED}$ binds to the monoaminooxidase B expressed in reactive astrocytes. Many efforts are currently being made to develop new PET tracers for specific receptors such as P2X, which is involved in the activation of microglial cells by the ATP provided from neuronal death, cannabinoid receptor subtype 2 (CB2) [138], which is overexpressed by activated microglial cells, and specific enzymes such as Cox-2 and MMP-9 that are upregulated. In addition, different binding affinity patterns for TSPO have been identified in humans according to the genetic status of the subjects, which could have an influence on the interpretation of the findings obtained from imaging $[70,139]$.

Brain imaging of microglial activation could help elucidate the biological variables involved and especially the relationship of microglial activation with the hallmarks of the disease and the temporal sequence of events leading to cognitive decline. Until now, PET imaging of neuroinflammation has concentrated on its relationship with the hallmark of the disease, amyloid deposition, which has revealed that the cognitive status of AD subjects is inversely correlated with microglial activation but not with amyloid load [60,90]. Even if activated microglia is known to be a component of $A \beta$ plaques in the brains of patients with $A D$, the association of microglia with $A \beta$ plaques is probably a function of the plaque type. Consequently, soluble $A \beta$ oligomers or fibrillar $A \beta$ (plaques) should be considered to have an affinity for microglial activation tracers. In fact, preclinical studies reported that soluble $A \beta$ oligomer could be an even more deleterious substance than fibrillar A $\beta$ [140] that can activate microglia and stimulate secretion of cytokines. Actually, the development of A $\beta$-PET imaging agents has allowed us to detect fibrillar $A \beta$ deposition in vivo [77]. But we still have to resolve the question of the relationship between microglial activation and tau pathology. Brain molecular imaging of tau pathology is limited. $\left[{ }^{18} \mathrm{~F}\right]$ FDDNP [2-(1-[89]ethylidene)malononitrile] is the only molecular PET probe that provides a measure of both amyloid and tau [89, 141-143]. Additional tau PET ligands are currently under development in animal and human brain studies, for example $\left[{ }^{18} \mathrm{~F}\right] \mathrm{T} 807$ [144] or THK523i [145], and may provide a new perspective on the relationship between neuroinflammation and $\mathrm{AD}$ pathology which is not restricted to $\mathrm{A} \beta$. 
Hommet et al.: Neuroinflammation and $\beta$ Amyloid Deposition in Alzheimer's Disease:

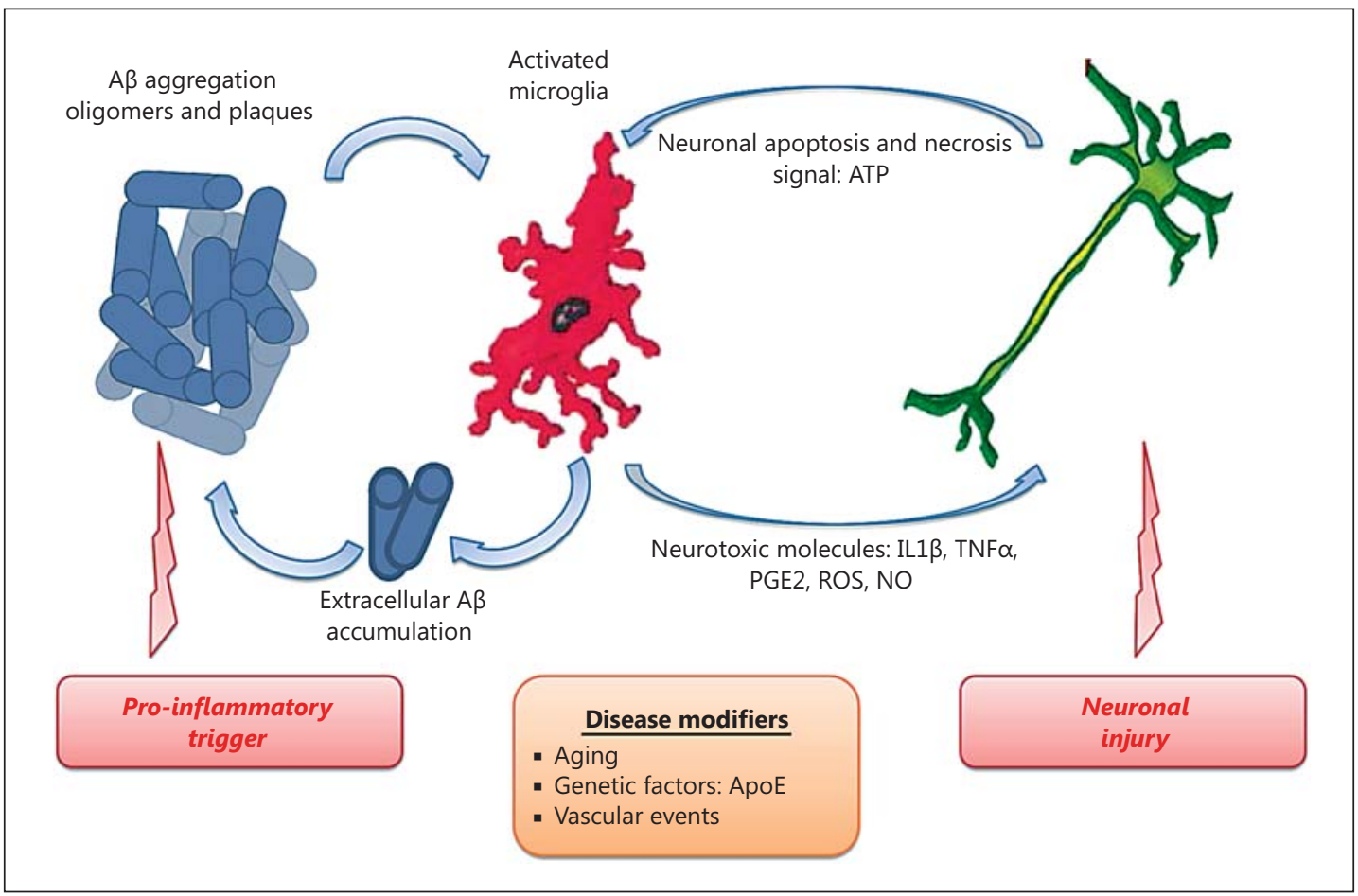

Fig. 2. Inflammation in AD. Amyloid accumulation forms aggregates that activate microglia. This phenomenon induces the production of reactive oxygen species (ROS), nitric oxide (NO) and the expression of cytokines.

The role of inflammatory processes may be different considering AD 'subtypes', according to different levels of $A \beta$ and tau, in addition to the presence or absence of the APOE $\varepsilon 4$ allele (fig. 2). With respect to the molecular imaging of neuroinflammation in $\mathrm{AD}$, only 2 papers assessed the relationship between neuroinflammation and other biomarkers of the disease, especially $\left[{ }^{18} \mathrm{~F}\right] \mathrm{FDG}[69,90]$. Carter et al. [69] reported no significant relationship between the different PET tracers $\left[{ }^{11} \mathrm{C}\right] \mathrm{DED},\left[{ }^{11} \mathrm{C}\right] \mathrm{PIB}$ and $\left[{ }^{18} \mathrm{~F}\right] \mathrm{FDG}$. CSF values $(\mathrm{A} \beta 42$, tau and $\mathrm{p}$-tau $)$ were reported in some of the $\mathrm{AD}$ and $\mathrm{MCI}$ subjects included in the studies, but the authors did not study the correlation between these CSF values and [ $\left.{ }^{11} \mathrm{C}\right]$ PIB BP. Yokokura et al. [90] confirmed no significant correlations between $\left[{ }^{11} \mathrm{C}\right] \mathrm{PK}-11195$ and [18F]FDG standardized uptake values in any region involved. The APOE gene product may be an important determinant of microglial activity in AD, as was reported in a postmortem study of AD brains with the APOE $\varepsilon 4$ gene [146]. Since $\left[{ }^{18} \mathrm{~F}\right] \mathrm{FDG}$ imaging reported brain changes before the onset of clinical symptoms in carriers of the APOE $\varepsilon 4$ allele [147-150], the combination of the cerebral metabolic rate with the pattern of neuroinflammation measured with PET molecular imaging and the genetic risk factors could be useful for detecting preclinical AD subjects and for assessing experimental therapies for prevention.

Finally, future developments in the molecular imaging of microglial activation may contribute to improving our understanding of the relationship between neuroinflammation, affective symptoms and the pathophysiology of $\mathrm{AD}$. The depression syndromes in geriatric patients may be mediated by inflammatory processes [151]. Indeed, epidemiological studies have demonstrated an association between elevated peripheral cytokines and depressive symptoms in elderly subjects [151-154]. Some recent preclinical studies have reported the results of antidepressant treatment on amyloid load using mouse models of $\operatorname{AD}[155,156]$. 
These findings also support the idea that there is a close relationship between AD and depression which involves neuroinflammation. Moreover, recent papers have reported that systemic inflammation (with increased serum TNF $\alpha$ and IL-6) was associated with an increase in cognitive decline [126] and with an exacerbation of neuropsychiatric symptoms [157]. Finally, brain imaging of microglial activation could add to our understanding of the physiopathology of atypical AD syndromes [7], like Benson's syndrome or logopenic aphasia.

\section{Aging}

The profile of microglial activation in the aging brain remains undetermined and could explain the variable results found in MCI subjects. Aging is associated with glial activation and increased production of inflammatory mediators [158]. Murine models supported the view that aging is accompanied by impairment in microglial functionality [159]. Microglial senescence and degeneration could compromise the neuroprotective function of microglial cells [160]. However, little is known about the role of microglia in healthy elderly subjects. Some studies have reported that increased levels of inflammatory markers were associated with impairment in cognitive functions, especially levels of IL-6 and -8 [161, 162]. Only a few molecular imaging studies have addressed microglial activation in healthy elderly controls. Cagnin et al. [58] studied adults aged 32-80 years and reported that $\left[{ }^{11} \mathrm{C}\right] \mathrm{PK}-11195$ binding did not significantly change with age except in the thalamus. Kumar et al. [163] studied the age-related changes in the distribution and expression of TSPO with $\left[{ }^{11} \mathrm{C}\right] \mathrm{PK}-11195$ in 15 healthy adults (mean age $29 \pm 8.5$ years) and 10 children (mean age $8.8 \pm 5.2$ years). The overall pattern of $\left[{ }^{11} \mathrm{C}\right] \mathrm{PK}-11195$ distribution in the brain was the same in the adults and in the children, although the intensity of uptake was increased in specific regions such as the midbrain and thalamus, contrasting with a lower uptake in the frontal, parietal and temporal cortex [163]. More recently, Schuitemaker et al. [128] reported an increase in the specific binding of $\left[{ }^{11} \mathrm{C}\right] \mathrm{PK}-11195$ with aging in healthy subjects (19-79 years old) in several cortical and subcortical areas (frontal cortex, anterior and posterior cingulate cortex, medial inferior temporal lobe, insula, hippocampus, entorhinal cortex, thalamus, parietal and occipital cortex and cerebellum) [128]. Gulyas et al. [164] used PET with $\left[{ }^{11} \mathrm{C}\right]$ vinpocetine, another TSPO radioligand, to study microglial activation during normal brain aging (healthy volunteers aged between 25 and 78 years) and reported increased uptake and binding with age in the entire brain and in all the brain regions studied. The significance of the age-related increase in $\left[{ }^{11} \mathrm{C}\right] \mathrm{PK}-11195$-specific binding remains undetermined. First of all, we wonder how important it is to consider the degree of neuronal brain damage. In fact, the previously reported studies were cross-sectional and did not quantify the amyloid lesions or the cognitive functions. Even if the neuropsychological performances of the subjects included were normal, we cannot totally eliminate the existence of preclinical AD in some of them. The second consideration concerns the quantitative interpretation of the signal binding pattern of subjects with respect to the TSPO radiotracer. In fact, different patients have different affinity patterns for TSPO ligands. Caution should be used in interpreting this fact because differences in PET signals according to the subjects studied are not necessarily related to differences in target density and may reflect individual variability in binding affinity related to an underlying genetic mechanism [70-72]. Binding affinity and selectivity for TSPO may vary according to the radioligands.

\section{Conclusions}

In $\mathrm{AD}$, activated microglia may prove to be an important therapeutic target, since microglial activation may be involved in neurodegenerative processes as early as in the prodromal stage. PET imaging with TSPO radioligands provides an interesting tool that 
should improve our understanding of the progression and the severity of neuroinflammation and perhaps provide us with an indicator of the prognosis of the disease. Longitudinal studies are needed to evaluate the role of neuroinflammation in prodromal AD in order to determine whether microglial activation, when detected early in $\mathrm{AD}$, is beneficial rather than detrimental.

The association of microglial activation with disease progression could help us to determine the prognosis of AD subjects and, subsequently, to target specific subgroups of AD patients with a higher risk of rapid cognitive decline. It could also potentially improve the assessment of the probability of disease progression and specific treatment strategies could be adapted, as more invasive and potentially harmful disease-modifying treatments for AD become available [165].

Consequently, molecular imaging of brain TSPO, as well as amyloid imaging, may help identify new therapeutic targets and monitor the results of future clinical trials aimed at preventive and therapeutic treatments. Molecular imaging of microglial activation could help us document the central inflammatory status of study subjects and assist us in designing future research studies, particularly with respect to determining which subjects to enroll into clinical trials, and could help us evaluate the benefit of specific therapies in selected groups, for example, by monitoring the effects of $A \beta$ immunization [166]. Results from clinical trials suggest that neuroinflammation plays an additional role in the different stages of the disease.

Microglial activation in vivo is a promising avenue of research in AD. It can be detected before the onset of dementia and could be predictive of the disease processes at an early stage. PET imaging of activated microglia could help elucidate the role of activated microglia in the pathogenesis of $\mathrm{AD}$ and supply us with prognostic information in order to stratify MCI subgroups at increased risk for developing $\mathrm{AD}$ and, in addition, help establish treatment strategies and monitor therapeutic efficacy.

\section{Disclosure Statement}

The authors disclose no sponsorship or funding arrangements relating to the paper.

\section{Acknowledgements}

The authors thank Dr. Donald Schwartz who revised the English version.

\section{References}

1 Braak H, Braak E: Neuropathological stageing of Alzheimer-related changes. Acta Neuropathol 1991;82:239259.

- 2 Morris JC: Early-stage and preclinical Alzheimer disease. Alzheimer Dis Assoc Disord 2005;19:163-165.

- 3 Dubois B, Feldman H, Jacova C, Cummings J, Dekosky ST, Barberger-Gateau P: Revising the definition of Alzheimer's disease: a new lexicon. Lancet Neurol 2010;9:1118-1127.

- 4 Dubois B, Feldman HH, Jacova C, Dekosky ST, Barberger-Gateau P, Cummings J, et al: Research criteria for the diagnosis of Alzheimer's disease: revising the NINCDS-ADRDA criteria. Lancet Neurol 2007;6:734-746.

5 Sperling RA, Aisen PS, Beckett LA, Bennett DA, Craft S, Fagan AM, et al: Toward defining the preclinical stages of Alzheimer's disease: recommendations from the National Institute on Aging-Alzheimer's Association workgroups on diagnostic guidelines for Alzheimer's disease. Alzheimers Dement 2011;7:280-292.

6 Albert MS, DeKosky ST, Dickson D, Dubois B, Feldman HH, Fox NC, et al: The diagnosis of mild cognitive impairment due to Alzheimer's disease: recommendations from the National Institute on Aging-Alzheimer's Association workgroups on diagnostic guidelines for Alzheimer's disease. Alzheimers Dement 2011;7:270-279.

- 7 McKhann GM, Knopman DS, Chertkow H, Hyman BT, Jack CR Jr, Kawas CH, et al: The diagnosis of dementia due to Alzheimer's disease: recommendations from the National Institute on Aging-Alzheimer's Association workgroups on diagnostic guidelines for Alzheimer's disease. Alzheimers Dement 2011;7:263-269. 
Hommet et al.: Neuroinflammation and $\beta$ Amyloid Deposition in Alzheimer's Disease:

In vivo Quantification with Molecular Imaging

8 Jack CR Jr, Knopman DS, Jagust WJ, Shaw LM, Aisen PS, Weiner MW, et al: Hypothetical model of dynamic biomarkers of the Alzheimer's pathological cascade. Lancet Neurol 2010;9:119-128.

9 McGeer PL, Itagaki S, Boyes BE, McGeer EG: Reactive microglia are positive for HLA-DR in the substantia nigra of Parkinson's and Alzheimer's disease brains. Neurology 1988;38:1285-1291.

10 Venneti S, Wiley CA, Kofler J: Imaging microglial activation during neuroinflammation and Alzheimer's disease. J Neuroimmune Pharmacol 2009;4:227-243.

11 Stalder M, Phinney A, Probst A, Sommer B, Staufenbiel M, Jucker M: Association of microglia with amyloid plaques in brains of APP23 transgenic mice. Am J Pathol 1999;154:1673-1684.

12 Leung E, Guo L, Bu J, Maloof M, El Khoury J, Geula C: Microglia activation mediates fibrillar amyloid-beta toxicity in the aged primate cortex. Neurobiol Aging 2011;32:387-397.

13 Frautschy SA, Yang F, Irrizarry M, Hyman B, Saido TC, Hsiao K, et al: Microglial response to amyloid plaques in APPsw transgenic mice. Am J Pathol 1998;152:307-317.

14 Akiyama H, Barger S, Barnum S, Bradt B, Bauer J, Cole GM, et al: Inflammation and Alzheimer's disease. Neurobiol Aging 2000;21:383-421.

15 Chauveau F, Van Camp N, Dolle F, Kuhnast B, Hinnen F, Damont A, et al: Comparative evaluation of the translocator protein radioligands 11C-DPA-713, 18F-DPA-714, and 11C-PK11195 in a rat model of acute neuroinflammation. J Nucl Med 2009;50:468-476.

16 Heneka MT, O’Banion MK: Inflammatory processes in Alzheimer's disease. J Neuroimmunol 2007;184:69-91.

17 Meda L, Cassatella MA, Szendrei GI, Otvos L Jr, Baron P, Villalba M, et al: Activation of microglial cells by betaamyloid protein and interferon-gamma. Nature 1995;374:647-650.

18 Wyss-Coray T, Mucke L: Inflammation in neurodegenerative disease - a double-edged sword. Neuron 2002; 35:419-432.

19 McGeer PL, Itagaki S, Tago H, McGeer EG: Reactive microglia in patients with senile dementia of the Alzheimer type are positive for the histocompatibility glycoprotein HLA-DR. Neurosci Lett 1987;79:195-200.

20 Nagele RG, D'Andrea MR, Lee H, Venkataraman V, Wang HY: Astrocytes accumulate A beta 42 and give rise to astrocytic amyloid plaques in Alzheimer disease brains. Brain Res 2003;971:197-209.

21 Heneka MT, Sastre M, Dumitrescu-Ozimek L, Hanke A, Dewachter I, Kuiperi C, et al: Acute treatment with the PPARgamma agonist pioglitazone and ibuprofen reduces glial inflammation and Abeta1-42 levels in APPV717I transgenic mice. Brain 2005;128(Pt 6):1442-1453.

22 Heneka MT, O’Banion MK, Terwel D, Kummer MP: Neuroinflammatory processes in Alzheimer's disease. J Neural Transm 2010;117:919-947.

23 Jacobs AH, Tavitian B: Noninvasive molecular imaging of neuroinflammation. J Cereb Blood Flow Metab 2012; 32:1393-1415

24 Meda L, Baron P, Scarlato G: Glial activation in Alzheimer's disease: the role of Abeta and its associated proteins. Neurobiol Aging 2001;22:885-893.

25 Morgan D, Gordon MN, Tan J, Wilcock D, Rojiani AM: Dynamic complexity of the microglial activation response in transgenic models of amyloid deposition: implications for Alzheimer therapeutics. J Neuropathol Exp Neurol 2005;64:743-753.

26 Tuppo EE, Arias HR: The role of inflammation in Alzheimer's disease. Int J Biochem Cell Biol 2005;37:289-305.

27 Winkeler A, Boisgard R, Martin A, Tavitian B: Radioisotopic imaging of neuroinflammation. J Nucl Med 2010; 51:1-4.

28 Hickman SE, Allison EK, El Khoury J: Microglial dysfunction and defective beta-amyloid clearance pathways in aging Alzheimer's disease mice. J Neurosci 2008;28:8354-8360.

29 Tan ZS, Seshadri S: Inflammation in the Alzheimer's disease cascade: culprit or innocent bystander? Alzheimers Res Ther 2010;2:6.

30 Baranowska-Bik A, Bik W, Wolinska-Witort E, Martynska L, Chmielowska M, Barcikowska M, et al: Plasma beta amyloid and cytokine profile in women with Alzheimer's disease. Neuro Endocrinol Lett 2008;29:75-79.

31 Ray S, Britschgi M, Herbert C, Takeda-Uchimura Y, Boxer A, Blennow K, et al: Classification and prediction of clinical Alzheimer's diagnosis based on plasma signaling proteins. Nat Med 2007;13:1359-1362.

32 Lee KS, Chung JH, Choi TK, Suh SY, Oh BH, Hong CH: Peripheral cytokines and chemokines in Alzheimer's disease. Dement Geriatr Cogn Disord 2009;28:281-287.

33 Reale M, Iarlori C, Feliciani C, Gambi D: Peripheral chemokine receptors, their ligands, cytokines and Alzheimer's disease. J Alzheimers Dis 2008;14:147-159.

34 Couturier J, Morel M, Pontcharraud R, Gontier V, Fauconneau B, Paccalin M, et al: Interaction of doublestranded RNA-dependent protein kinase (PKR) with the death receptor signaling pathway in amyloid beta (Abeta)-treated cells and in APPSLPS1 knock-in mice. J Biol Chem 2010;285:1272-1282.

35 Miscia S, Ciccocioppo F, Lanuti P, Velluto L, Bascelli A, Pierdomenico L, et al: Abeta(1-42) stimulated T cells express P-PKC-delta and P-PKC-zeta in Alzheimer disease. Neurobiol Aging 2009;30:394-406.

36 Town T, Tan J, Flavell RA, Mullan M: T-cells in Alzheimer's disease. Neuromolecular Med 2005;7:255-264.

37 Rezai-Zadeh K, Gate D, Gowing G, Town T: How to get from here to there: macrophage recruitment in Alzheimer's disease. Curr Alzheimer Res 2011;8:156-163.

38 Galimberti D, Schoonenboom N, Scheltens P, Fenoglio C, Bouwman F, Venturelli E, et al: Intrathecal chemokine synthesis in mild cognitive impairment and Alzheimer disease. Arch Neurol 2006;63:538-543.

39 Ruan L, Kong Y, Wang JM, Le Y: Chemoattractants and receptors in Alzheimer's disease. Front Biosci (Schol Ed) $2010 ; 2: 504-514$. 
Hommet et al.: Neuroinflammation and $\beta$ Amyloid Deposition in Alzheimer's Disease:

In vivo Quantification with Molecular Imaging

40 Westin K, Buchhave P, Nielsen H, Minthon L, Janciauskiene S, Hansson O: CCL2 is associated with a faster rate of cognitive decline during early stages of Alzheimer's disease. PLoS One 2012; 7:e30525.

41 Kim TS, Lim HK, Lee JY, Kim DJ, Park S, Lee C, et al: Changes in the levels of plasma soluble fractalkine in patients with mild cognitive impairment and Alzheimer's disease. Neurosci Lett 2008;436:196-200.

42 Stewart WF, Kawas C, Corrada M, Metter EJ: Risk of Alzheimer's disease and duration of NSAID use. Neurology 1997;48:626-632.

43 McGeer PL, McGeer EG: NSAIDs and Alzheimer disease: epidemiological, animal model and clinical studies. Neurobiol Aging 2007;28:639-647.

44 McGeer PL, Schulzer M, McGeer EG: Arthritis and anti-inflammatory agents as possible protective factors for Alzheimer's disease: a review of 17 epidemiologic studies. Neurology 1996;47:425-432.

45 Vlad SC, Miller DR, Kowall NW, Felson DT: Protective effects of NSAIDs on the development of Alzheimer disease. Neurology 2008;70:1672-1677.

46 Breitner JC, Baker LD, Montine TJ, Meinert CL, Lyketsos CG, Ashe KH, et al: Extended results of the Alzheimer's disease anti-inflammatory prevention trial. Alzheimers Dement 2011;7:402-411.

47 Lichtenstein MP, Carriba P, Masgrau R, Pujol A, Galea E: Staging anti-inflammatory therapy in Alzheimer's disease. Front Aging Neurosci 2010;2:142.

48 Doorduin J, Klein HC, Dierckx RA, James M, Kassiou M, de Vries EF: [11C]-DPA-713 and [18F]-DPA-714 as new PET tracers for TSPO: a comparison with [11C]-(R)-PK11195 in a rat model of herpes encephalitis. Mol Imaging Biol 2009;11:386-398.

49 Gulyas B, Makkai B, Kasa P, Gulya K, Bakota L, Varszegi S, et al: A comparative autoradiography study in post mortem whole hemisphere human brain slices taken from Alzheimer patients and age-matched controls using two radiolabelled DAA1106 analogues with high affinity to the peripheral benzodiazepine receptor (PBR) system. Neurochem Int 2009;54:28-36.

50 Venneti S, Wang G, Nguyen J, Wiley CA: The positron emission tomography ligand DAA1106 binds with high affinity to activated microglia in human neurological disorders. J Neuropathol Exp Neurol 2008;67:10011010.

51 Chen MK, Guilarte TR: Translocator protein $18 \mathrm{kDa}$ (TSPO): molecular sensor of brain injury and repair. Pharmacol Ther 2008;118:1-17.

52 Martin A, Boisgard R, Theze B, Van Camp N, Kuhnast B, Damont A, et al: Evaluation of the PBR/TSPO radioligand [(18)F]DPA-714 in a rat model of focal cerebral ischemia. J Cereb Blood Flow Metab 2010;30:230-241.

53 Cagnin A, Kassiou M, Meikle SR, Banati RB: Positron emission tomography imaging of neuroinflammation. Neurotherapeutics 2007;4:443-452.

54 Rojas S, Martin A, Arranz MJ, Pareto D, Purroy J, Verdaguer E, et al: Imaging brain inflammation with [(11)C] PK11195 by PET and induction of the peripheral-type benzodiazepine receptor after transient focal ischemia in rats. J Cereb Blood Flow Metab 2007;27:1975-1986.

55 Schroeter M, Dennin MA, Walberer M, Backes H, Neumaier B, Fink GR, et al: Neuroinflammation extends brain tissue at risk to vital peri-infarct tissue: a double tracer [11C]PK11195- and [18F]FDG-PET study. J Cereb Blood Flow Metab 2009;29:1216-1225.

56 Gerhard A, Schwarz J, Myers R, Wise R, Banati RB: Evolution of microglial activation in patients after ischemic stroke: a [11C](R)-PK11195 PET study. Neuroimage 2005;24:591-595.

57 Price CJ, Wang D, Menon DK, Guadagno JV, Cleij M, Fryer T, et al: Intrinsic activated microglia map to the periinfarct zone in the subacute phase of ischemic stroke. Stroke 2006;37:1749-1753.

58 Cagnin A, Brooks DJ, Kennedy AM, Gunn RN, Myers R, Turkheimer FE, et al: In-vivo measurement of activated microglia in dementia. Lancet 2001;358:461-467.

59 Venneti S, Lopresti BJ, Wiley CA: The peripheral benzodiazepine receptor (translocator protein $18 \mathrm{kDa}$ ) in microglia: from pathology to imaging. Prog Neurobiol 2006;80:308-322.

60 Edison P, Archer HA, Gerhard A, Hinz R, Pavese N, Turkheimer FE, et al: Microglia, amyloid, and cognition in Alzheimer's disease: an [11C](R)PK11195-PET and [11C]PIB-PET study. Neurobiol Dis 2008;32:412-419.

61 Kropholler MA, Boellaard R, van Berckel BN, Schuitemaker A, Kloet RW, Lubberink MJ, et al: Evaluation of reference regions for (R)-[(11)C]PK11195 studies in Alzheimer's disease and mild cognitive impairment. J Cereb Blood Flow Metab 2007;27:1965-1974.

62 Versijpt JJ, Dumont F, Van Laere KJ, Decoo D, Santens P, Audenaert K, et al: Assessment of neuroinflammation and microglial activation in Alzheimer's disease with radiolabelled PK11195 and single photon emission computed tomography. A pilot study. Eur Neurol 2003;50:39-47.

63 Schuitemaker A, Kropholler MA, Boellaard R, van der Flier WM, Kloet RW, van der Doef TF, et al: Microglial activation in Alzheimer's disease: an (R)-[(1)(1)C]PK11195 positron emission tomography study. Neurobiol Aging 2013;34:128-136.

64 Fujimura Y, Ikoma Y, Yasuno F, Suhara T, Ota M, Matsumoto R, et al: Quantitative analyses of 18F-FEDAA1106 binding to peripheral benzodiazepine receptors in living human brain. J Nucl Med 2006;47:43-50.

65 Fujita M, Imaizumi M, Zoghbi SS, Fujimura Y, Farris AG, Suhara T, et al: Kinetic analysis in healthy humans of a novel positron emission tomography radioligand to image the peripheral benzodiazepine receptor, a potential biomarker for inflammation. Neuroimage 2008;40:43-52.

66 Yasuno F, Ota M, Kosaka J, Ito H, Higuchi M, Doronbekov TK, et al: Increased binding of peripheral benzodiazepine receptor in Alzheimer's disease measured by positron emission tomography with [11C]DAA1106. Biol Psychiatry 2008;64:835-841. 
Hommet et al.: Neuroinflammation and $\beta$ Amyloid Deposition in Alzheimer's Disease:

In vivo Quantification with Molecular Imaging

67 Yasuno F, Kosaka J, Ota M, Higuchi M, Ito H, Fujimura Y, et al: Increased binding of peripheral benzodiazepine receptor in mild cognitive impairment-dementia converters measured by positron emission tomography with [(11)C]DAA1106. Psychiatry Res 2012;203:67-74.

68 Varrone A, Mattsson P, Forsberg A, Takano A, Nag S, Gulyas B, et al: In vivo imaging of the 18-kDa translocator protein (TSPO) with [18F]FEDAA1106 and PET does not show increased binding in Alzheimer's disease patients. Eur J Nucl Med Mol Imaging 2013;40:921-931.

69 Carter SF, Scholl M, Almkvist O, Wall A, Engler H, Langstrom B, et al: Evidence for astrocytosis in prodromal Alzheimer disease provided by 11C-deuterium-L-deprenyl: a multitracer PET paradigm combining 11C-Pittsburgh compound B and 18F-FDG. J Nucl Med 2012;53:37-46.

70 Kreisl WC, Fujita M, Fujimura Y, Kimura N, Jenko KJ, Kannan P, et al: Comparison of [(11)C]-(R)-PK 11195 and [(11)C]PBR28, two radioligands for translocator protein $(18 \mathrm{kDa})$ in human and monkey: implications for positron emission tomographic imaging of this inflammation biomarker. Neuroimage 2010;49:2924-2932.

71 Owen DR, Yeo AJ, Gunn RN, Song K, Wadsworth G, Lewis A, et al: An 18-kDa translocator protein (TSPO) polymorphism explains differences in binding affinity of the PET radioligand PBR28. J Cereb Blood Flow Metab 2011;32:1-5.

72 Owen DR, Gunn RN, Rabiner EA, Bennacef I, Fujita M, Kreisl WC, et al: Mixed-affinity binding in humans with 18-kDa translocator protein ligands. J Nucl Med 2011;52:24-32.

73 James ML, Fulton RR, Vercoullie J, Henderson DJ, Garreau L, Chalon S, et al: DPA-714, a new translocator proteinspecific ligand: synthesis, radiofluorination, and pharmacologic characterization. J Nucl Med 2008;49:814-822.

74 Arlicot N, Vercouillie J, Ribeiro MJ, Tauber C, Venel Y, Baulieu JL, et al: Initial evaluation in healthy humans of [18F]DPA-714, a potential PET biomarker for neuroinflammation. Nucl Med Biol 2012;39:570-578.

75 Corcia P, Tauber C, Vercoullie J, Arlicot N, Prunier C, Praline J, et al: Molecular imaging of microglial activation in amyotrophic lateral sclerosis. PLoS One 2012;7:e52941.

76 Liberati A, Altman DG, Tetzlaff J, Mulrow C, Gotzsche PC, Ioannidis JP, et al: The PRISMA statement for reporting systematic reviews and meta-analyses of studies that evaluate health care interventions: explanation and elaboration. Ann Intern Med 2009;151:W65-W94.

77 Klunk WE, Engler H, Nordberg A, Wang Y, Blomqvist G, Holt DP, et al: Imaging brain amyloid in Alzheimer's disease with Pittsburgh compound-B. Ann Neurol 2004;55:306-319.

78 Herholz K, Ebmeier K: Clinical amyloid imaging in Alzheimer's disease. Lancet Neurol 2011;10:667-670.

79 Lin KJ, Hsu WC, Hsiao IT, Wey SP, Jin LW, Skovronsky D, et al: Whole-body biodistribution and brain PET imaging with [18F]AV-45, a novel amyloid imaging agent - a pilot study. Nucl Med Biol 2010;37:497-508.

80 Wong DF, Rosenberg PB, Zhou Y, Kumar A, Raymont V, Ravert HT, et al: In vivo imaging of amyloid deposition in Alzheimer disease using the radioligand 18F-AV-45 (florbetapir [corrected] F 18). J Nucl Med 2010;51: 913-920.

81 Camus V, Payoux P, Barre L, Desgranges B, Voisin T, Tauber C, et al: Using PET with 18F-AV-45 (florbetapir) to quantify brain amyloid load in a clinical environment. Eur J Nucl Med Mol Imaging 2012;39:621-631.

82 Clark CM, Schneider JA, Bedell BJ, Beach TG, Bilker WB, Mintun MA, et al: Use of florbetapir-PET for imaging beta-amyloid pathology. JAMA 2011;305:275-283.

83 Sperling RA, Johnson KA, Doraiswamy PM, Reiman EM, Fleisher AS, Sabbagh MN, et al: Amyloid deposition detected with florbetapir F 18 ((18)F-AV-45) is related to lower episodic memory performance in clinically normal older individuals. Neurobiol Aging 2013;34:822-831.

84 Doraiswamy PM, Sperling RA, Coleman RE, Johnson KA, Reiman EM, Davis MD, et al: Amyloid-beta assessed by florbetapir F 18 PET and 18-month cognitive decline: a multicenter study. Neurology 2012;79:1636-1644.

85 Fleisher AS, Chen K, Liu X, Roontiva A, Thiyyagura P, Ayutyanont N, et al: Using positron emission tomography and florbetapir F18 to image cortical amyloid in patients with mild cognitive impairment or dementia due to Alzheimer disease. Arch Neurol 2011;68:1404-1411.

86 Rowe CC, Ackerman U, Browne W, Mulligan R, Pike KL, O'Keefe G, et al: Imaging of amyloid beta in Alzheimer's disease with 18F-BAY94-9172, a novel PET tracer: proof of mechanism. Lancet Neurol 2008;7:129-135.

87 Barthel H, Sabri O: Florbetaben to trace amyloid-beta in the Alzheimer brain by means of PET. J Alzheimers Dis 2011;26(suppl 3):117-121.

88 Vandenberghe R, Van Laere K, Ivanoiu A, Salmon E, Bastin C, Triau E, et al: 18F-flutemetamol amyloid imaging in Alzheimer disease and mild cognitive impairment: a phase 2 trial. Ann Neurol 2010;68:319-329.

89 Small GW, Kepe V, Ercoli LM, Siddarth P, Bookheimer SY, Miller KJ, et al: PET of brain amyloid and tau in mild cognitive impairment. N Engl J Med 2006;355:2652-2663.

90 Yokokura M, Mori N, Yagi S, Yoshikawa E, Kikuchi M, Yoshihara Y, et al: In vivo changes in microglial activation and amyloid deposits in brain regions with hypometabolism in Alzheimer's disease. Eur J Nucl Med Mol Imaging 2011;38:343-351.

91 Wiley CA, Lopresti BJ, Venneti S, Price J, Klunk WE, DeKosky ST, et al: Carbon 11-labeled Pittsburgh compound B and carbon 11-labeled (R)-PK11195 positron emission tomographic imaging in Alzheimer disease. Arch Neurol 2009;66:60-67.

92 Okello A, Edison P, Archer HA, Turkheimer FE, Kennedy J, Bullock R, et al: Microglial activation and amyloid deposition in mild cognitive impairment: a PET study. Neurology 2009;72:56-62.

93 Santillo AF, Gambini JP, Lannfelt L, Langstrom B, Ulla-Marja L, Kilander L, et al: In vivo imaging of astrocytosis in Alzheimer's disease: an (1)(1)C-L-deuteriodeprenyl and PIB PET study. Eur J Nucl Med Mol Imaging 2011; 38:2202-2208. 
94 Schmidt C, Wolff M, Weitz M, Bartlau T, Korth C, Zerr I: Rapidly progressive Alzheimer disease. Arch Neurol 2011;68:1124-1130.

95 Carcaillon L, Peres K, Pere JJ, Helmer C, Orgogozo JM, Dartigues JF: Fast cognitive decline at the time of dementia diagnosis: a major prognostic factor for survival in the community. Dement Geriatr Cogn Disord 2007;23:439-445.

96 Helmer C, Andrieu S, Peres K, Orgogozo JM, Vellas B, Dartigues JF: Predictive value of 6-month decline in ADAS-cog for survival without severe Alzheimer's disease. Dement Geriatr Cogn Disord 2007;23:168-174.

97 Dumont C, Voisin T, Nourhashemi F, Andrieu S, Koning M, Vellas B: Predictive factors for rapid loss on the mini-mental state examination in Alzheimer's disease. J Nutr Health Aging 2005;9:163-167.

98 Hui JS, Wilson RS, Bennett DA, Bienias JL, Gilley DW, Evans DA: Rate of cognitive decline and mortality in Alzheimer's disease. Neurology 2003;61:1356-1361.

99 Schmidt C, Redyk K, Meissner B, Krack L, von Ahsen N, Roeber S, et al: Clinical features of rapidly progressive Alzheimer's disease. Dement Geriatr Cogn Disord 2010;29:371-378.

100 Yesavage JA, Brooks JO 3rd, Taylor J, Tinklenberg J: Development of aphasia, apraxia, and agnosia and decline in Alzheimer's disease. Am J Psychiatry 1993;150:742-747.

101 Lopez OL, Wisnieski SR, Becker JT, Boller F, DeKosky ST: Extrapyramidal signs in patients with probable Alzheimer disease. Arch Neurol 1997;54:969-975.

102 Palmer K, Lupo F, Perri R, Salamone G, Fadda L, Caltagirone C, et al: Predicting disease progression in Alzheimer's disease: the role of neuropsychiatric syndromes on functional and cognitive decline. J Alzheimers Dis 2010;24:35-45.

103 Soto ME, Secher M, Gillette-Guyonnet S, Abellan van Kan G, Andrieu S, Nourhashemi F, et al: Weight loss and rapid cognitive decline in community-dwelling patients with Alzheimer's disease. J Alzheimers Dis 2012;28: 647-654.

104 Wilson RS, Tang Y, Aggarwal NT, Gilley DW, McCann JJ, Bienias JL, et al: Hallucinations, cognitive decline, and death in Alzheimer's disease. Neuroepidemiology 2006;26:68-75.

105 Lopez OL, Schwam E, Cummings J, Gauthier S, Jones R, Wilkinson D, et al: Predicting cognitive decline in Alzheimer's disease: an integrated analysis. Alzheimers Dement 2010;6:431-439.

106 Wattmo C, Wallin AK, Londos E, Minthon L: Predictors of long-term cognitive outcome in Alzheimer's disease. Alzheimers Res Ther 2011;3:23.

107 Craft S, Teri L, Edland SD, Kukull WA, Schellenberg G, McCormick WC, et al: Accelerated decline in apolipoprotein E-epsilon4 homozygotes with Alzheimer's disease. Neurology 1998;51:149-153.

108 van der Vlies AE, Koedam EL, Pijnenburg YA, Twisk JW, Scheltens P, van der Flier WM: Most rapid cognitive decline in APOE epsilon4 negative Alzheimer's disease with early onset. Psychol Med 2009;39:1907-1911.

109 Regan C, Katona C, Walker Z, Hooper J, Donovan J, Livingston G: Relationship of vascular risk to the progression of Alzheimer disease. Neurology 2006;67:1357-1362.

110 Borroni B, Archetti S, Ferrari M, Cesana BM, Padovani A: Relationship of vascular risk to the progression of Alzheimer disease. Neurology 2007;68:1083-1084; author reply 4.

111 Bhargava D, Weiner MF, Hynan LS, Diaz-Arrastia R, Lipton AM: Vascular disease and risk factors, rate of progression, and survival in Alzheimer's disease. J Geriatr Psychiatry Neurol 2006;19:78-82.

112 Abellan van Kan G, Rolland Y, Nourhashemi F, Coley N, Andrieu S, Vellas B: Cardiovascular disease risk factors and progression of Alzheimer's disease. Dement Geriatr Cogn Disord 2009;27:240-246.

113 Mielke MM, Rosenberg PB, Tschanz J, Cook L, Corcoran C, Hayden KM, et al: Vascular factors predict rate of progression in Alzheimer disease. Neurology 2007;69:1850-1858.

114 Helzner EP, Luchsinger JA, Scarmeas N, Cosentino S, Brickman AM, Glymour MM, et al: Contribution of vascular risk factors to the progression in Alzheimer disease. Arch Neurol 2009;66:343-348.

115 Smith EE, Egorova S, Blacker D, Killiany RJ, Muzikansky A, Dickerson BC, et al: Magnetic resonance imaging white matter hyperintensities and brain volume in the prediction of mild cognitive impairment and dementia. Arch Neurol 2008;65:94-100.

116 Debette S, Bombois S, Bruandet A, Delbeuck X, Lepoittevin S, Delmaire C, et al: Subcortical hyperintensities are associated with cognitive decline in patients with mild cognitive impairment. Stroke 2007;38:2924-2930.

117 DeCarli C, Mungas D, Harvey D, Reed B, Weiner M, Chui H, et al: Memory impairment, but not cerebrovascular disease, predicts progression of MCI to dementia. Neurology 2004;63:220-227.

118 Wolf H, Ecke GM, Bettin S, Dietrich J, Gertz HJ: Do white matter changes contribute to the subsequent development of dementia in patients with mild cognitive impairment? A longitudinal study. Int J Geriatr Psychiatry 2000;15:803-812.

119 Bombois S, Debette S, Bruandet A, Delbeuck X, Delmaire C, Leys D, et al: Vascular subcortical hyperintensities predict conversion to vascular and mixed dementia in MCI patients. Stroke 2008;39:2046-2051.

120 Staekenborg SS, Koedam EL, Henneman WJ, Stokman P, Barkhof F, Scheltens P, et al: Progression of mild cognitive impairment to dementia: contribution of cerebrovascular disease compared with medial temporal lobe atrophy. Stroke 2009;40:1269-1274.

121 Cordonnier C, van der Flier WM, Sluimer JD, Leys D, Barkhof F, Scheltens P: Prevalence and severity of microbleeds in a memory clinic setting. Neurology 2006;66:1356-1360.

122 Yakushiji Y, Nishiyama M, Yakushiji S, Hirotsu T, Uchino A, Nakajima J, et al: Brain microbleeds and global cognitive function in adults without neurological disorder. Stroke 2008;39:3323-3328. 
Hommet et al.: Neuroinflammation and $\beta$ Amyloid Deposition in Alzheimer's Disease:

In vivo Quantification with Molecular Imaging

123 Hommet C, Mondon K, Constans T, Beaufils E, Desmidt T, Camus V, et al: Review of cerebral microangiopathy and Alzheimer's disease: relation between white matter hyperintensities and microbleeds. Dement Geriatr Cogn Disord 2011;32:367-378.

124 Lo RY, Jagust WJ: Vascular burden and Alzheimer disease pathologic progression. Neurology 2012;79:13491355.

125 Prasad K, Wiryasaputra L, Ng A, Kandiah N: White matter disease independently predicts progression from mild cognitive impairment to Alzheimer's disease in a clinic cohort. Dement Geriatr Cogn Disord 2011;31: 431-434.

126 Holmes C, Cunningham C, Zotova E, Woolford J, Dean C, Kerr S, et al: Systemic inflammation and disease progression in Alzheimer disease. Neurology 2009;73:768-774.

127 Trollor JN, Smith E, Baune BT, Kochan NA, Campbell L, Samaras K, et al: Systemic inflammation is associated with MCI and its subtypes: the Sydney Memory and Aging Study. Dement Geriatr Cogn Disord 2010;30:569578.

128 Schuitemaker A, van der Doef TF, Boellaard R, van der Flier WM, Yaqub M, Windhorst AD, et al: Microglial activation in healthy aging. Neurobiol Aging 2012;33:1067-1072.

129 Jessen F, Wiese B, Bachmann C, Eifflaender-Gorfer S, Haller F, Kolsch H, et al: Prediction of dementia by subjective memory impairment: effects of severity and temporal association with cognitive impairment. Arch Gen Psychiatry 2010;67:414-422.

130 Reisberg B, Shulman MB, Torossian C, Leng L, Zhu W: Outcome over seven years of healthy adults with and without subjective cognitive impairment. Alzheimers Dement 2010;6:11-24.

131 Wang L, van Belle G, Crane PK, Kukull WA, Bowen JD, McCormick WC, et al: Subjective memory deterioration and future dementia in people aged 65 and older. J Am Geriatr Soc 2004;52:2045-2051.

132 McKhann G, Drachman D, Folstein M, Katzman R, Price D, Stadlan EM: Clinical diagnosis of Alzheimer's disease: report of the NINCDS-ADRDA Work Group under the auspices of Department of Health and Human Services Task Force on Alzheimer's Disease. Neurology 1984;34:939-944.

133 Petersen RC, Doody R, Kurz A, Mohs RC, Morris JC, Rabins PV, et al: Current concepts in mild cognitive impairment. Arch Neurol 2001;58:1985-1992.

134 Nizri E, Irony-Tur-Sinai M, Faranesh N, Lavon I, Lavi E, Weinstock M, et al: Suppression of neuroinflammation and immunomodulation by the acetylcholinesterase inhibitor rivastigmine. J Neuroimmunol 2008;203: $12-22$.

135 Gouw AA, Seewann A, van der Flier WM, Barkhof F, Rozemuller AM, Scheltens P, et al: Heterogeneity of small vessel disease: a systematic review of MRI and histopathology correlations. J Neurol Neurosurg Psychiatry 2011;82:126-135.

136 Gouw AA, Seewann A, Vrenken H, van der Flier WM, Rozemuller JM, Barkhof F, et al: Heterogeneity of white matter hyperintensities in Alzheimer's disease: post-mortem quantitative MRI and neuropathology. Brain 2008;131(Pt 12):3286-3298.

137 Gulyas B, Toth M, Vas A, Shchukin E, Kostulas K, Hillert J, et al: Visualising neuroinflammation in post-stroke patients: a comparative PET study with the TSPO molecular imaging biomarkers [11C]PK11195 and [11C] vinpocetine. Curr Radiopharm 2012;5:19-28.

138 Horti AG, Gao Y, Ravert HT, Finley P, Valentine H, Wong DF, et al: Synthesis and biodistribution of [11C] A-836339, a new potential radioligand for PET imaging of cannabinoid type 2 receptors (CB2). Bioorg Med Chem 2010;18:5202-5207.

139 Kreisl WC, Jenko KJ, Hines CS, Hyoung Lyoo C, Corona W, Morse CL, et al: A genetic polymorphism for translocator protein $18 \mathrm{kDa}$ affects both in vitro and in vivo radioligand binding in human brain to this putative biomarker of neuroinflammation. J Cereb Blood Flow Metab 2013;33:53-58.

140 Wyss-Coray T: Inflammation in Alzheimer disease: driving force, bystander or beneficial response? Nat Med 2006;12:1005-1015.

141 Shin J, Kepe V, Barrio JR, Small GW: The merits of FDDNP-PET imaging in Alzheimer's disease. J Alzheimers Dis 2011;26(suppl 3):135-145.

142 Thompson PW, Ye L, Morgenstern JL, Sue L, Beach TG, Judd DJ, et al: Interaction of the amyloid imaging tracer FDDNP with hallmark Alzheimer's disease pathologies. J Neurochem 2009;109:623-630.

143 Tauber C, Beaufils E, Hommet C, Ribeiro MJ, Vercouille J, Vierron E, et al: Brain [18F]FDDNP binding and glucose metabolism in advanced elderly healthy subjects and Alzheimer's disease patients. J Alzheimers Dis 2013;36:311-320.

144 Xia CF, Arteaga J, Chen G, Gangadharmath U, Gomez LF, Kasi D, et al: [(18)F]T807, a novel tau positron emission tomography imaging agent for Alzheimer's disease. Alzheimers Dement 2013, E-pub ahead of print.

145 Fodero-Tavoletti MT, Okamura N, Furumoto S, Mulligan RS, Connor AR, McLean CA, et al: 18F-THK523: a novel in vivo tau imaging ligand for Alzheimer's disease. Brain 2011;134(Pt 4):1089-1100.

146 Egensperger R, Kosel S, von Eitzen U, Graeber MB: Microglial activation in Alzheimer disease: association with APOE genotype. Brain Pathol 1998;8:439-447.

147 Reiman EM, Caselli RJ, Chen K, Alexander GE, Bandy D, Frost J: Declining brain activity in cognitively normal apolipoprotein E epsilon 4 heterozygotes: a foundation for using positron emission tomography to efficiently test treatments to prevent Alzheimer's disease. Proc Natl Acad Sci USA 2001;98:3334-3339.

148 Reiman EM, Chen K, Alexander GE, Caselli RJ, Bandy D, Osborne D, et al: Functional brain abnormalities in young adults at genetic risk for late-onset Alzheimer's dementia. Proc Natl Acad Sci USA 2004;101:284-289. 
149 Small GW, Mazziotta JC, Collins MT, Baxter LR, Phelps ME, Mandelkern MA, et al: Apolipoprotein E type 4 allele and cerebral glucose metabolism in relatives at risk for familial Alzheimer disease. JAMA 1995;273:942-947.

150 Small GW, Ercoli LM, Silverman DHS, Huang SC, Bookheimer SY, Lavretsky H, et al: Influence of apoE genotype and PET brain imaging on preclinical prediction of Alzheimer's Disease; in Iqbal K, Sisodia SS, Winblad B (eds): Alzheimer's Disease: Advances in Etiology, Pathogenesis and Therapeutics. Chichester, John Wiley \& Sons Ltd, 2001.

151 Alexopoulos GS, Morimoto SS: The inflammation hypothesis in geriatric depression. Int J Geriatr Psychiatry 2011;26:1109-1118.

152 Maes M: Depression is an inflammatory disease, but cell-mediated immune activation is the key component of depression. Prog Neuropsychopharmacol Biol Psychiatry 2010;35:664-675.

153 Maes M: A review on the acute phase response in major depression. Rev Neurosci 1993;4:407-416.

154 Maes M, Bosmans E, De Jongh R, Kenis G, Vandoolaeghe E, Neels H: Increased serum IL-6 and IL-1 receptor antagonist concentrations in major depression and treatment resistant depression. Cytokine 1997;9:853858.

155 Cirrito JR, Disabato BM, Restivo JL, Verges DK, Goebel WD, Sathyan A, et al: Serotonin signaling is associated with lower amyloid-beta levels and plaques in transgenic mice and humans. Proc Natl Acad Sci USA 2011;108: 14968-14973.

156 Chavant F, Deguil J, Pain S, Ingrand I, Milin S, Fauconneau B, et al: Imipramine, in part through tumor necrosis factor alpha inhibition, prevents cognitive decline and beta-amyloid accumulation in a mouse model of Alzheimer's disease. J Pharmacol Exp Ther 2010;332:505-514.

157 Holmes C, Cunningham C, Zotova E, Culliford D, Perry VH: Proinflammatory cytokines, sickness behavior, and Alzheimer disease. Neurology 2011;77:212-218.

158 Sheng JG, Mrak RE, Griffin WS: Enlarged and phagocytic, but not primed, interleukin-1 alpha-immunoreactive microglia increase with age in normal human brain. Acta Neuropathol 1998;95:229-234.

159 Streit WJ, Miller KR, Lopes KO, Njie E: Microglial degeneration in the aging brain - bad news for neurons? Front Biosci 2008;13:3423-3438.

160 Norden DM, Godbout JP: Review: microglia of the aged brain: primed to be activated and resistant to regulation. Neuropathol Appl Neurobiol 2013;39:19-34.

161 Baune BT, Ponath G, Rothermundt M, Riess O, Funke H, Berger K: Association between genetic variants of IL-1beta, IL-6 and TNF-alpha cytokines and cognitive performance in the elderly general population of the MEMO-study. Psychoneuroendocrinology 2008;33:68-76.

162 Komulainen P, Lakka TA, Kivipelto M, Hassinen M, Penttila IM, Helkala EL, et al: Serum high sensitivity C-reactive protein and cognitive function in elderly women. Age Ageing 2007;36:443-448.

163 Kumar A, Muzik O, Shandal V, Chugani D, Chakraborty P, Chugani HT: Evaluation of age-related changes in translocator protein (TSPO) in human brain using 11C-[R]-PK11195 PET. J Neuroinflammation 2012;9:232.

164 Gulyas B, Vas A, Toth M, Takano A, Varrone A, Cselenyi Z, et al: Age and disease related changes in the translocator protein (TSPO) system in the human brain: positron emission tomography measurements with [11C] vinpocetine. Neuroimage 2011;56:1111-1121.

165 Appleby BS, Nacopoulos D, Milano N, Zhong K, Cummings JL: A review: treatment of Alzheimer's disease discovered in repurposed agents. Dement Geriatr Cogn Disord 2013;35:1-22.

166 Zotova E, Holmes C, Johnston D, Neal JW, Nicoll JA, Boche D: Microglial alterations in human Alzheimer's disease following Abeta42 immunization. Neuropathol Appl Neurobiol 2011;37:513-524. 